\title{
ENTERPRISE ARCHITECTURE - NEW BUSINESS VALUE PERSPECTIVES
}

\author{
M. de Vries ${ }^{1}$ and A.C. J van Rensburg ${ }^{2}$ \\ ${ }^{1}$ Department of Industrial and Systems Engineering \\ University of Pretoria, South Africa \\ ${ }^{1}$ marne.devries@up.ac.za, ${ }^{2}$ antoniej@up.ac.za
}

\begin{abstract}
Organisations today are characterised by conglomerate organisation structures that evolve through mergers and acquisitions. Corporate offices need to add superior knowledge and skills to ensure that the collection of diverse businesses is operating as more than independent units. A new management approach is required to create synergies between the diverse businesses, their processes and system landscapes. Enterprise Architecture (EA) creates value on a corporate level by facilitating process/information technology alignment and synergy between different strategic business units (SBUs). Unfortunately many EA implementations seemed to fail owing to a short-term financial focus and measurement.
\end{abstract}

This article explores the possibilities of linking EA to a corporate balanced scorecard (BSC) to demonstrate its long-term financial improvement capabilities in supporting the business strategy. The aim is to use the corporate BSC context to direct EA objectives in creating contextualised value for a specific enterprise.

\section{OPSOMMING}

Organisasies word vandag gekenmerk deur konglomeraatorganisasiestrukture wat groei deur middel van die samesmelting en oorname van ander organisasies. Korporaatkantore sal hoër-staande kennis en vaardighede moet toevoeg om te verseker dat die versameling van diverse besighede groter is as wanneer hul onafhanklik van mekaar opereer. 'n Nuwe bestuursbenadering word benodig om sinergieë tussen die diverse besighede, hul prosesse en stelsel-landskappe te skep. Ondernemingsargitektuur (OA) skep waarde op 'n korporatiewe vlak deur die fasilitering van proses/inligtingtegnologiebelyning en sinergie-skepping tussen verskillende strategiese besigheidseenhede. Ongelukkig faal vele OA projekte weens 'n kort-termyn finansiële fokus en prestasie-meting.

Hierdie artikel ondersoek die moontlikheid om OA te koppel aan 'n korporatiewe gebalanseerde telkaart (KBT) om sodanig OA se lang-termyn finansiële verbeteringsvermoë ter ondersteuning van besigheidstrategie te demonstreer. Die KBT konteks word dus gebruik om OA doelwitte te rig om gekontekstualiseerde waarde vir 'n spesifieke ondernening te skep. 


\section{INTRODUCTION}

In the 1970s and 1980s, business processes were redesigned roughly once every seven years. This provided ample time to alter information systems. In the 1990s the rate of change started to increase rapidly, and information systems lagged behind. Today IT departments struggle to keep up with the rapid change of business processes (Wagter, van den Berg, Luijpers \& van Steenberg [1]).

Looking at the history of enterprise architecture, different eras become apparent:

The mainframe era required a centralised approach. The need for EA was minimal as a limited set of resources had to be managed. However, the centralised IT departments failed to meet the demands of business users.

As technology evolved and became more accessible, organisational units began to evolve, each one deploying its own systems to improve service. The decentralised approach led to an expansion of system complexity and a loss of functionality between departments.

The loss of control led to ERP (Enterprise Resource Planning) systems as a solution to complex, multiple, fragmented, and non-interoperable legacy systems. But these ERP systems were very costly, demanded ongoing maintenance, and required major system modifications to address business processes. Also, mergers and acquisitions once again diversified and complicated the system landscape (Theuerkorn [2]).

The complex system landscapes of today led to the need to manage the evolution of system and technology environments, which in turn led to the emergence of a new profession called Enterprise Architecture (EA).

\section{ENTERPRISE ARCHITECTURE}

\subsection{Definition and value proposition}

EA is a management practice that aims at improving performance of enterprises. EA gained impetus with the USA Clinger-Cohen Act (CCA) of 1996. This act assigned the $\mathrm{CIO}$ the responsibility of "developing, maintaining, and facilitating the implementation of a sound and integrated Information Technology Architecture" (Schekkerman [3]). The Information Technology Architecture (ITA) had to ensure that existing information technology was maintained and new information technology was acquired to achieve the agency's strategic goals and information resources management goals.

In the past, EA was the responsibility of the IT unit(s) in a company. However, many IT architecture efforts were remote from reality, and were represented in overlycomplex diagrams. Companies defined strategy piece-meal, which delivered separate IT solutions for each strategic initiative, rather than delivering IT capabilities. This resulted in IT being a constant bottleneck. Standalone systems were created, causing poor customer, supplier, and employee process coordination. Data were also patchy, error-prone and not up to date (Ross, Weill, \& Robertson [4]). Currently companies realise that EA is not an IT issue, but a business issue. 
According to Ross et al [4] EA should strive at providing “...the high-level logic for business processes and IT capabilities". They realised that EA is not so much to achieve a particular end state as it is to serve as a blueprint for a company's direction. EA should provide a "holistic and integrated view of the strategic direction, business practices, information flows, and technology resources" of the company (Bernard [5]). The main EA concepts are:

- $\quad$ strategic planning deliverables that direct EA objectives;

- a technology charter (enterprise objectives, principles and guidelines and derived technology objectives, principles and guidelines);

- a technology roadmap (milestones to evolve the system landscape) that is derived from the technology charter;

- $\quad$ project requirements that are identified to meet the technology milestones;

- a methodology (including methods, tools and standards) that is used to support the evolution of the system landscape; and

- a framework that classifies EA models to communicate to various stakeholder groups.

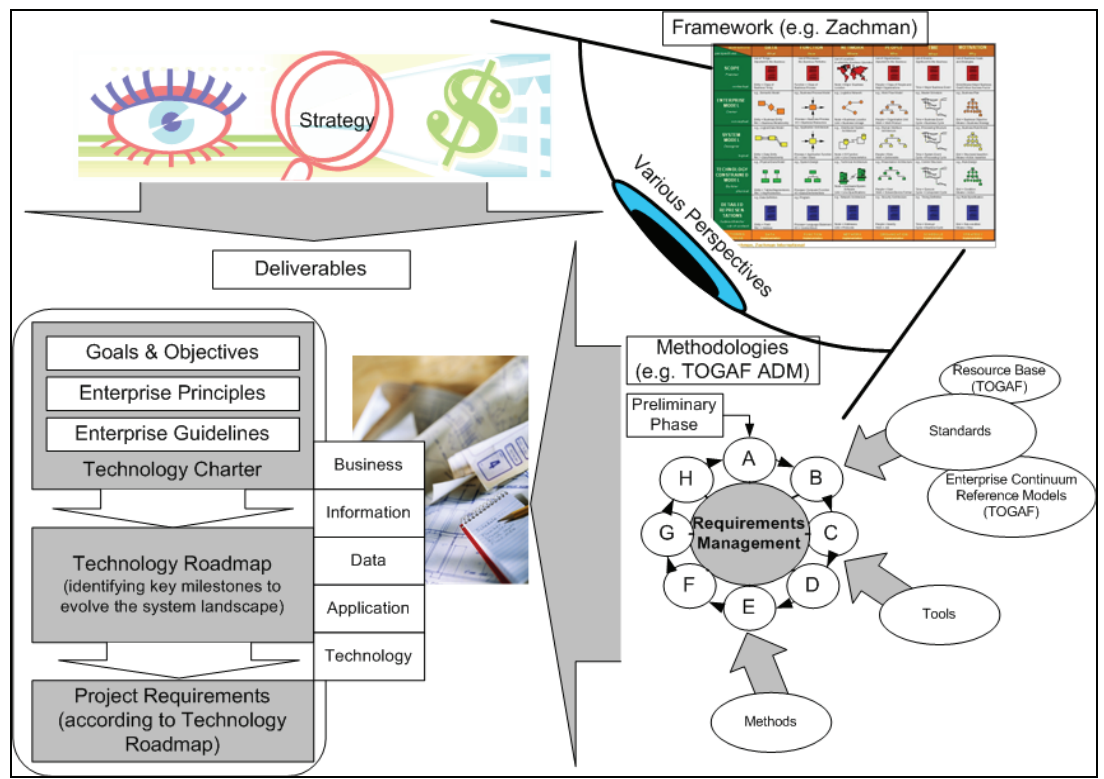

Figure 1: Conceptual framework for EA 


\subsection{Research problem and goal of the study}

Although EA offers numerous benefits and value propositions, many organisations perceived EA as another black hole that provided a low return on investment if measured by the traditional financial measurement system. EA practitioners tried to improve the EA practices, frameworks, methodologies, and tools to reduce the number of artefacts and/or to accelerate the implementation of EA governance mechanisms (Theuerkorn [2] and Wagter et al [1]). Although Ross et al [4] realised the importance of using EA as a blueprint in directing a company, they still failed to demonstrate how EA objectives should be measured or how they could be converted to tangible value.

EA creates value on different management levels in the organisation across multiple domains (e.g. governance, strategy, business processes, information, applications, technology, workforce management, security, and standards). Literature also indicates that EA as a management programme complements various other areas. Some of these include strategic planning, strategy execution, quality management, IT governance (e.g. complementing COBIT - Control Objectives for Information and related Technology), IT Service Delivery and Support (e.g. supporting the key processes of ITIL - IT Infrastructure Library), and IT Implementation (supporting the implementation of best practices) (Lankhorst [6]).

An integrated approach is required to demonstrate how EA creates tangible value on both enterprise level and strategic business unit (SBU) level, across different domains. Kaplan \& Norton [7,8,9] provide numerous tools to create synergies, alignment, and integration of intangible assets on different organisational management levels. The next section describes how intangible assets create value on both an enterprise level and SBU level. The management level perspectives are then used to discuss generic EA objectives, their relation to other strategic objectives, and links to performance measurement.

\section{DIFFERENT PERSPECTIVES ON VALUE CREATION}

During the same time that EA was initiated as a management practice, Kaplan \& Norton [7] identified a major shortcoming in the traditional measurement systems. These overemphasised achieving and maintaining short-term financial results (i.e. high ROI) that lead to overinvestment in short-term fixes and underinvestment in long-term value creation - especially underinvestment in intangible and intellectual assets that generate future growth. Kaplan \& Norton [7] contributed to the new understanding of what creates value for organisations. Intangible assets (e.g. motivated/skilled employees, responsive and predictable internal processes, and satisfied customers) are some of the most important sources of long-term value creation. Unfortunately traditional financial measurement systems merely focused on tangible assets.

A more balanced measurement system was proposed to incorporate four perspectives: financial, customer, internal processes, and learning and growth (Kaplan \& Norton [7]). They believed that companies had to invest in these four domains to create both short-term financial improvement and long-term profitable growth. They also realised that companies that wanted to survive and prosper in the 
information age competition had to use measurement and management systems that are derived from their strategies and capabilities. The balanced scorecard (BSC) was developed to account for the different measurement perspectives, and provided a systematic process of implementing and obtaining feedback about strategy.

With the balanced perspective on organisational measurement, Kaplan \& Norton [8] posed new value-creation perceptions concerning intangible assets. They assert that intangible assets are usually bundled, seldom create value by themselves, and do not have a value that can be isolated from the organisational context and strategy. Intangible assets are expected to help the organisation accomplish the strategy; hence action plans should be aligned around strategic themes. Integrated bundles of investments should be linked to the strategic themes instead of managing standalone projects. Each investment or initiative is "only an ingredient in the bigger recipe" (Kaplan \& Norton [8]). Economic justification should only be determined by evaluating the return from the entire portfolio of investments in intangible assets.

Kaplan \& Norton [9] also realised that the conglomerate and multidivisional organisation structures of today do not only achieve growth through expansions from the core business, technologies, and capabilities, but also through acquiring and merging unrelated businesses. Senior executives of these conglomerates need to add superior knowledge and skills to the newly-owned organisations to make the merger or acquisition worthwhile. The value of the collection of companies should thus be more than if the companies operated independently without the benefit of the corporate office.

Value creation on a corporate level consequently differs from value creation at a strategic business unit (SBU) level. Corporate offices need to create enterprisederived value, creating alignment and synergy between SBUs. On the other hand, SBUs need to show how their internal capabilities and assets are used to create customer-derived value. Different perspectives on value creation are demonstrated in Figure 2. The next two sections emphasise value-creation strategies at a corporate level and related EA value propositions.

\section{STRATEGIES TO CREATE CORPORATE SYNERGIES}

Various strategies could be used to create synergies on a corporate level. A few examples include:

- Financial perspective: using effective merger and acquisition policies or generating synergies by using centralised resource allocation and financial management.

- Customer perspective: leveraging common brand or customer relationships across different business units and retail channels.

- Internal process perspective: gaining economies of scale by sharing common processes and services or gaining economies of scope by integrating business units across an industry value chain.

- Learning and growth: creating synergies by sharing human, information, and organisation capital across multiple units (Kaplan \& Norton [9]). 


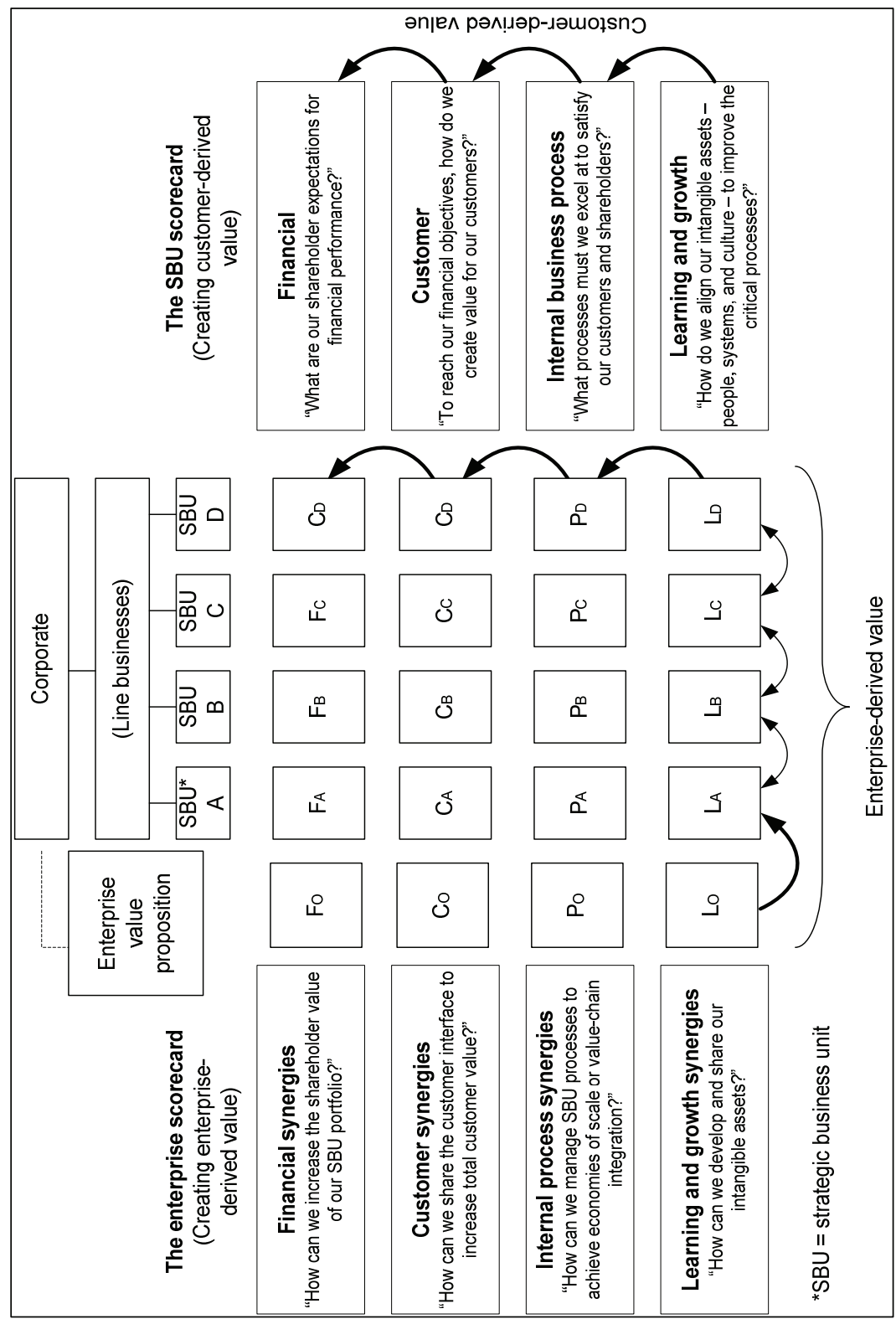

Figure 2: Building the enterprise scorecard (Kaplan \& Norton [9]) 
Ross et al [4] created an EA value proposition primarily in terms of the internal process perspective (gaining economies of scale by sharing common processes/ services or integrating processes). They believe that EA objectives should be defined with regards to the enterprise operating model. The operating model is an actionable view of the company's strategy that outlines the expectations for integration and standardisation across business units. The operating model is thus defined in terms of two dimensions:

- Business process standardisation - the extent to which the company benefits by having business units run their operations the same way.

- Business process integration - the extent to which different business units are dependent on one another for accurate and timely data. Different combinations of these dimensions are portrayed in Figure 3.

\begin{tabular}{|c|c|c|}
\hline 홈 & $\begin{array}{l}\text { Coordination } \\
\text { - Shared customers, products, or } \\
\text { - } \text { Imppliers } \\
\text { transact on other business unit } \\
\text { - Operationally unique business units } \\
\text { or functions } \\
\text { - Autonomous business management } \\
\text { - Business unit control over business } \\
\text { process design } \\
\text { - Shared customer/supplier/product } \\
\text { data } \\
\text { - Consensus processes for designing } \\
\text { IT infrastructure services; IT } \\
\text { application decisions made in } \\
\text { business unit }\end{array}$ & $\begin{array}{l}\text { Unification } \\
\text { - } \quad \text { Customers and suppliers may be } \\
\text { local or global } \\
\text { - Globally integrated business } \\
\text { processes often with support of } \\
\text { enterprise systems } \\
\text { - } \quad \text { Business units with similar or over- } \\
\text { lapping operations } \\
\text { - Centralised management often } \\
\text { applying functional/process/business } \\
\text { unit matrices } \\
\text { - High-level process owners design } \\
\text { standardised processes } \\
\text { - Centrally mandated databases } \\
\text { IT decisions made centrally }\end{array}$ \\
\hline & $\begin{array}{l}\text { Diversification } \\
\text { - } \text { Few, if any, shared customers or } \\
\text { suppliers } \\
\text { - Independent transactions } \\
\text { - Operationally unique business units } \\
\text { - } \text { Autonomous business management } \\
\text { - Business unit control over business } \\
\text { process design } \\
\text { - Few data standards across business } \\
\text { units } \\
\text { - Most IT decisions made within } \\
\text { business units }\end{array}$ & $\begin{array}{l}\text { Replication } \\
\text { - Few, if any, shared customers } \\
\text { - Independent transactions aggregated } \\
\text { at a high level } \\
\text { - Operationally similar business units } \\
\text { - Autonomous business unit leaders } \\
\text { - } \text { with limited discretion over processes } \\
\text { - } \text { bentralised (or federal) control over } \\
\text { - Standardised data definitions but } \\
\text { data locally owned with some } \\
\text { aggregation at corporate } \\
\text { - Centrally mandated IT services }\end{array}$ \\
\hline בذ & Low & High \\
\hline
\end{tabular}

Figure 3: Characteristics of four operating models (Ross et al [4]) 
The researcher used the operating model parameters to identify generic EA objectives within the areas of process management, data sharing, application management, and infrastructure. Figure 4 provides a proposed set of EA objectives for a required operating state.

\begin{tabular}{|c|c|c|c|c|c|}
\hline \multirow{2}{*}{$\begin{array}{l}\text { Architecture } \\
\text { Dimension }\end{array}$} & \multirow{2}{*}{ EA Objective } & \multicolumn{4}{|c|}{ Operating Model } \\
\hline & & Diversification & Coordination & Replication & Unification \\
\hline \multirow{3}{*}{$\begin{array}{l}\text { Process } \\
\text { Management }\end{array}$} & $\begin{array}{l}\text { To centralise } \\
\text { processes (versus } \\
\text { business unit } \\
\text { autonomy) } \\
\end{array}$ & No & No & Yes & Yes \\
\hline & \begin{tabular}{|l|} 
To centralise \\
standard process \\
designs (versus \\
control by \\
separate business \\
units) \\
\end{tabular} & No & No & Yes & Yes \\
\hline & $\begin{array}{l}\text { To integrate } \\
\text { processes } \\
\text { between different } \\
\text { business units. } \\
\end{array}$ & No & Yes & No & Yes \\
\hline \multirow{3}{*}{$\begin{array}{l}\text { Data } \\
\text { Sharing }\end{array}$} & $\begin{array}{l}\text { To share } \\
\text { customer data }\end{array}$ & No & \multirow{3}{*}{ Either } & No & Yes \\
\hline & $\begin{array}{l}\text { To share product } \\
\text { data }\end{array}$ & Indifferent & & Indifferent & Indifferent \\
\hline & $\begin{array}{l}\text { To share supplier } \\
\text { data }\end{array}$ & No & & Indifferent & Yes \\
\hline $\begin{array}{l}\text { Application } \\
\text { Management }\end{array}$ & $\begin{array}{l}\text { To centralise IT } \\
\text { application } \\
\text { decision making } \\
\text { (i.e. not } \\
\text { prescribed by } \\
\text { separate business } \\
\text { units) }\end{array}$ & No & No & Yes & Yes \\
\hline $\begin{array}{l}\text { Infra- } \\
\text { structure }\end{array}$ & \begin{tabular}{|l|} 
To create \\
consensus \\
processes for \\
designing IT \\
infrastructure \\
services
\end{tabular} & No & Yes & Yes & Yes \\
\hline
\end{tabular}

Figure 4: EA objectives per operating model (based on the four operatingmodels identified by Ross et al [4])

Ross et al [4] also complemented this model with a methodology for implementing the required operating model. The methodology acknowledges different levels of EA maturity and suggests a phased (project-by-project) approach. The methodology also includes some element of integration with other intangible assets (such as organisational learning and leadership requirements). It is proposed that the 
operating model approach could be further enhanced by mapping the EA objectives (related to a specific operating model) to a corporate strategy map.

To demonstrate the concept, the author mapped EA objectives for the unification operating model to a corporate strategy map. Additional EA objectives (as found in Schekkerman [3], Theuerkorn [2], Ross et al [4], Wagter et al [1], Boar [10], Iyamu [11]) were also included to demonstrate a comprehensive strategy map for EA capital (see Figure 5). The strategy map indicates that most EA objectives support the creation of process synergies and learning \& growth synergies between SBUs.

\section{USING STRATEGIC THEMES TO CREATE CORPORATE SYNERGIES}

Kaplan \& Norton [9] also report the effective use of corporate strategic themes to create synergy between business units. Examples of strategic themes include operational excellence, and complete solutions to targeted customers. The corporate strategic themes are used in combination with the corporate BSC to cascade strategic objectives to individual SBUs. SBU managers are then obliged to phase out local projects that are not contributing to one or more of the strategic themes.

The purpose is to create alignment and integration among the diverse and dispersed business units. Strategic themes in the corporate scorecard have the ability of allowing decentralised units to seek local gains while still contributing to corporatewide objectives. Due to the diversity of the business units, not all units are expected to contribute to all the themes. Kaplan \& Norton [8]) agree with Treacy \& Wiersma [12] that a single SBU usually focuses on one strategic theme, as it is impossible to excel in all areas simultaneously.

They identified three main strategic areas:

1. Operational excellence - the best total costs.

2. Customer intimacy - the best total solution/customised mix of products and services to solve customers' problems.

3. Product leadership - excel in the offering of products and services.

Hax \& Wilde [13] articulated a fourth strategic area, called 'system lock-in', in which companies provide a system platform that becomes an industry standard.

Kaplan \& Norton [8] combined the strategic areas with the four scorecard perspectives (financial, customer, internal processes, and learning \& growth) to discuss the different objectives that would be required for each strategic focus area. An SBU usually selects one strategic focus area (e.g. operational excellence) to direct the selection of primary strategic objectives within the four scorecard perspectives. Finally, strategy maps are used to link the different objectives (within the four perspectives) in cause-and-effect relationships. The learning and growth perspective objectives (cause) need to support the internal process objectives (effect). Furthermore, the internal process objectives (cause) need to enable the achievement of the customer objectives (effect), while the customer objectives (cause) need to contribute to the accomplishment of the financial objectives (effect). 


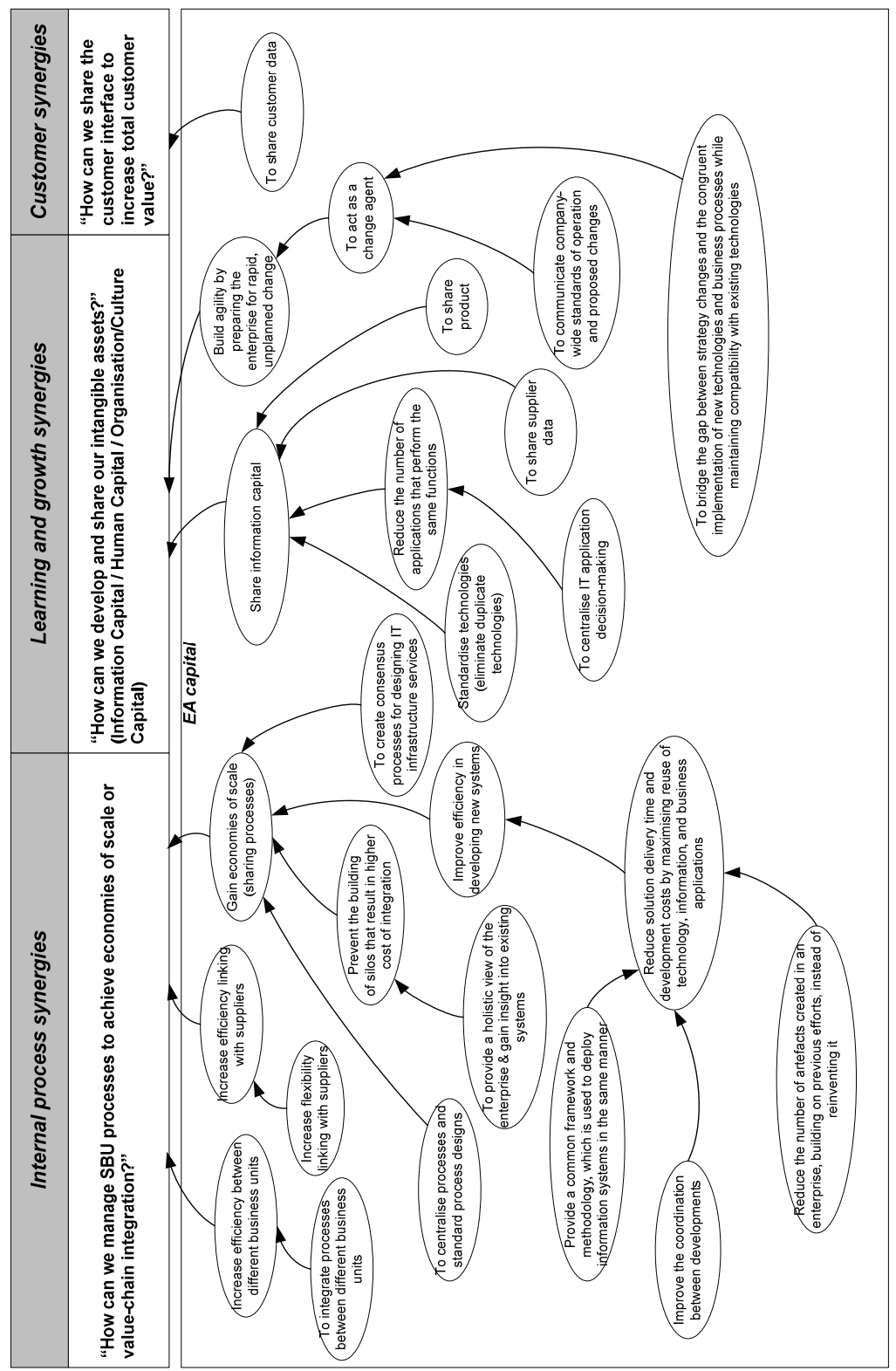

Figure 5: EA objectives linked to a corporate model 
Kaplan \& Norton [8] identified four categories of value-creating internal processes:

- $\quad$ Operations management processes;

- Customer management processes;

- Innovation processes; and

- Regulatory and social processes.

Different process objectives are required for each strategic focus area. The different process objectives are discussed and argued in the next two sections.

\subsection{Process objectives per focus area}

\section{Operational excellence/low total cost}

This focus area requires highly competitive processes combined with consistent quality, ease and speed of purchase, and excellent product selection. Customer management processes require ease of access for customers. Accessible order processes and superb post-sale services are required. The SBU would perform market research to understand the most preferred range of products and services by the largest segments of customers. SBUs that pursue this strategic focus are product followers, not leaders, and do not invest a great deal in product and service innovation. They innovate on processes rather than products. They also emphasise regulatory and social processes to avoid accidents and environmental incidents that are costly to the company (Norton \& Kaplan [8]).

\section{Customer intimacy}

SBUs offer 'customer solutions' value propositions that stress objectives related to the completeness of the solution (selling multiple bundled products and services), exceptional service, and a quality relationship. The company tries to deepen the relationship with current customers to sell multiple related products and services. Innovation processes focus on finding new ways to create value for customers, such as providing alternative ways for customers to access the company's products and services. Regulatory and social processes are focused on gaining regulatory approval to offer services that cut across traditional industry barriers (Norton \& Kaplan [8]).

\section{Product leadership}

SBUs that emphasise product leadership provide products with features and function-ality that leading-edge customers are willing to pay for. The value proposition includes outstanding performance, accuracy, size, or power consumption. Product leadership SBUs extend superior functionality of products into multiple market segments. Their key internal processes are in the innovation cluster. Flexibility and improvement of operating processes are more important than low-cost production. Customer management objectives include the identification of requirements from leading-edge customers, as well as educating customers about the benefits of new/advanced products. Regulatory and social processes must avoid 
the adverse side effects that may occur when they introduce new products. SBUs should emphasise objectives related to product safety, employee and customer health, and environmental impacts of new products (Norton \& Kaplan [8]).

\section{Lock-in}

The new economy information-based industries, such as computer hardware, software, internet, and telecommunications, led to lock-in strategies, creating high switching costs for customers. SBUs that pursue a lock-in strategy require powerful innovation processes. They need to develop a proprietary product or protected standard that serves as the basis for lock-in. As complementors provide a source of sustainability, SBUs need to acquire and retain complementors. They need to attract new customers by lowering their switching costs. High margins from successful lockin remove the pressure of having the most efficient operating processes. Two critical regulatory objectives must be pursued: protecting proprietary products from imitation and use by competitors, and preventing product-use by unauthorised customers (Norton \& Kaplan [8]).

\subsection{Operational excellence - the dominant theme?}

In the past, many SBUs (as well as industrial engineers) focused primarily on the area of operational excellence. They emphasised the improvement of existing processes that would lead to short term financial improvement. Various process/quality/productivity improvement programmes were developed and implemented (e.g. ISO 9001, Six Sigma, European Foundation for Quality Management, Capability Maturity Models, and Supply Chain Management programs). Norton \& Kaplan [7] believe, however, that some SBUs may benefit more in the long term by anticipating customer needs or delivering new services that target customers would value. Conversely, other business units may benefit most if they focus on their innovation processes, creating entirely new products and services.

Ross et al [4] believe that a SBU needs to recognise its core operations and digitise these to enable organisations to exploit their foundation for execution, which should lead to agility and profitable growth. The rationale is that digitising core business processes helps in automating some routine activities, making sure that these are done reliably and predictably. Management could then focus their attention on higher-order processes (serving customers, developing new products, seizing new opportunities). Their definition of core business processes thus implies a focus on a single process area, namely operational management. Norton \& Kaplan [8] agree that many SBUs first stabilise their operations and delivery processes to produce consistent output in conformity to specifications. The definition of quality then shifts from conforming to specifications to meeting customers' expectations. One could reason that an organisation's strategic focus area will change to customer intimacy/product leadership/ lock-in as the organisation reaches a certain level of maturity.

\section{A NEW VALUE-CREATION APPROACH}

Intangible assets do not have a value that can be isolated from the organisational context and strategy. They are expected to help the organisation to accomplish the 
strategy. EA, used in combination with the BSC, creates the context on a corporate level to ensure that intangible assets (especially value-creating processes and information capital) are integrated with other intangible assets and aligned around the strategic themes of the organisation. EA initiatives should be treated as part of an integrated bundle of investments, linked to strategic themes, instead of managing them as standalone projects. Economic justification should only be determined by evaluating the return from the entire portfolio of investment in intangible assets.

EA thus has the potential to produce corporate synergies between strategic business units, especially creating internal process synergies and learning \& growth synergies. Furthermore, EA objectives primarily support the operational excellence theme, which may be further differentiated using operating model parameters. EA objectives on the corporate level could then be cascaded to SBU level and division level to ensure alignment with the corporate scorecard objectives (

Figure 6).

\section{AN ANGLO PLATINUM EXAMPLE}

Anglo Platinum is the world's leading primary producer of platinum, and accounts for about $38 \%$ of the world's newly-mined production. Operations comprise seven mines, three smelters, a base metals refinery, and a precious metals refinery, situated in the Bushveld Complex north-west and north-east of Johannesburg. Anglo Platinum embarked on one of the most successful EA initiatives in the world; some critics consider them to be in the top 5\% globally [14]. The following narrative explains how Anglo Platinum followed an approach similar to the proposed valuecreation approach.

During 2004 corporate management restructured and effectively decided to move away from a diversified operating model to a replication operating model by centralising control over business process designs and providing clear corporate guidelines. Moving towards a replication operating model would enhance process synergies between the different business units. Corporate management also defined strategic themes to drive their strategic objectives. The most prominent themes were operational excellence and social upliftment.

The Group Information Collaboration Technology (ICT) division of Anglo Platinum received the mandate to identify value-creation process objectives as well as information and technology objectives according to the required operating model and aligned to the operational excellence theme. Contrary to the traditional IT department role of service provider, the role of Group ICT was to act as a decisionmaking body in defining business process requirements and information quality/requirements. The division, employing 120 people - predominantly business managers and a few technology experts - embarked on strategic work sessions to define strategic drivers and themes in directing their divisional strategic objectives. Finally, a strategy map was used to demonstrate the cause-and-effect links between their strategic objectives. Although these objectives embodied multiple EA objectives, EA did not feature as a separate theme or management approach. The prominent EA objectives were: 


\section{Kaplan \& Norton,}

2006, p8
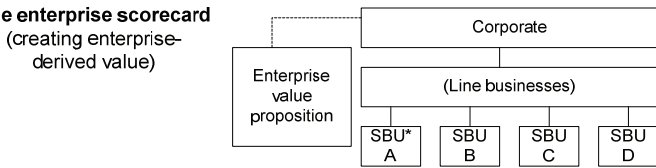

The enterprise strategy map (strategic themes)
Operational Other excellence themes Required operating model

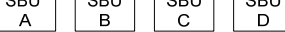

parameters

Financial synergies "How can we increase the shareholder value of our SBU portfolio?"
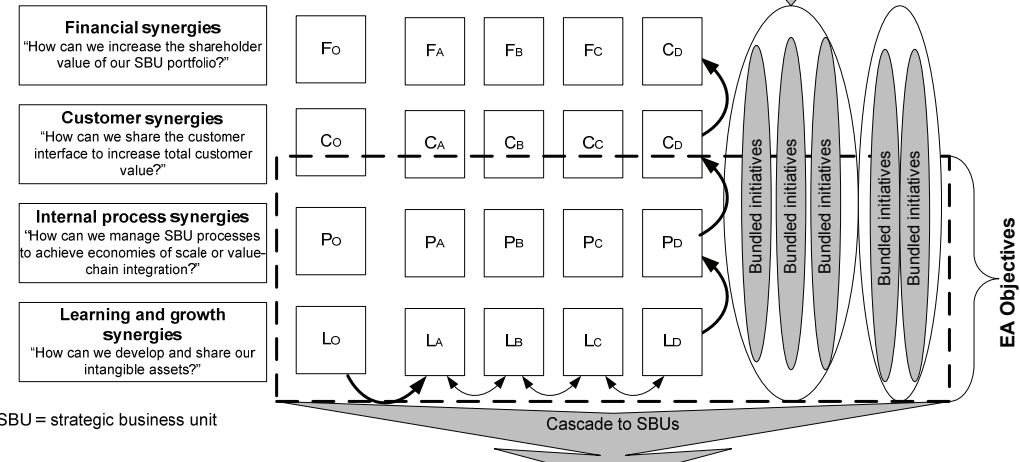

*SBU $=$ strategic business unit

Cascade to SBUs
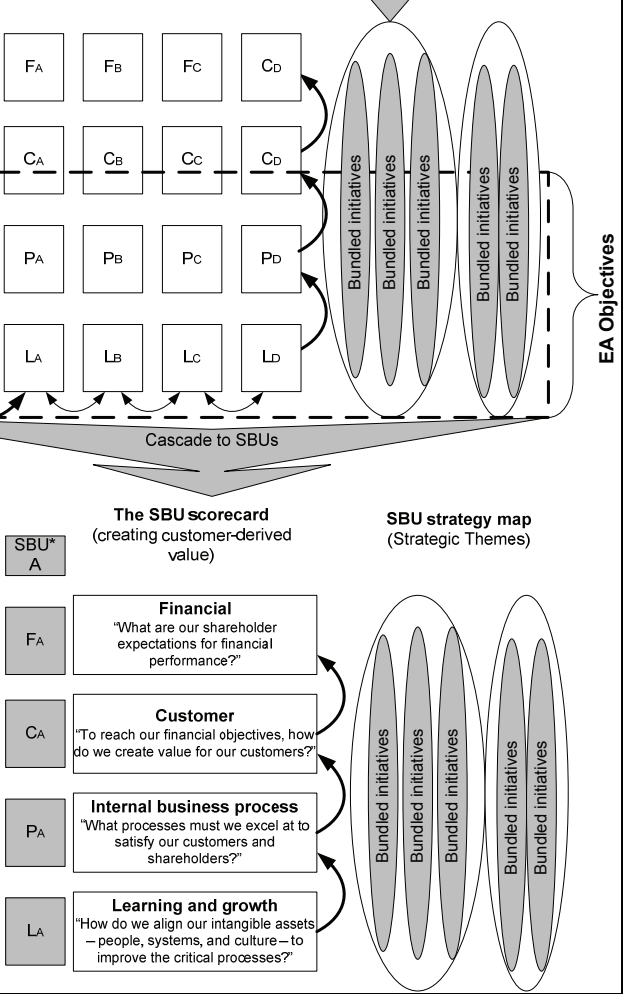

Figure 6: A value-creation approach for EA

- Standardisation of business processes to reduce complexity.

- Governance of standardised processes to ensure implementation and adherence on an operational level. 
The EA objectives primarily focused on the business architecture layer of the enterprise, and were combined with other projects (e.g. business process improvement and information value-chain initiatives) to form an integrated bundle of projects aligned to the operational excellence strategic theme. The standardisation and stabilisation of business processes provided a platform for continuous improvement. Simulation is currently considered as an innovation mechanism to drive continuous improvement.

\section{CONCLUSION}

In the past, many organisations overemphasised short-term return on investment rather than long-term financial improvement. This also had a negative effect on the perceived value of EA. Being an intangible asset, EA has the potential to unlock value if perceived in the context of strategy and long-term profitable growth. The corporate BSC and strategy map were used to demonstrate EA potential in creating process synergies and learning \& growth synergies. It was also found that EA objectives primarily support an operational excellence theme, while the sub-set of EA objectives is mainly determined by the operating model of the specific enterprise.

This research provided the context for EA planning in an enterprise. The suggested approach requires alignment between different intangible assets according to the theme of operational excellence. Further research will be done to demonstrate the alignment of EA with other intangible assets as part of the planning stages of themerelated initiatives.

\section{ACKNOWLEDGEMENTS}

This material is based upon work financially supported by the National Research Foundation. The researcher would also like to thank Mr Johan van Tonder at Anglo Platinum for his valuable inputs.

\section{REFERENCES}

[1] Wagter, R., van den Berg, M., Luijpers, J. \& van Steenberg, M. 2005. Dynamic Enterprise Architecture - How to make it work. John Wiley \& Sons, Inc., Hoboken, New Jersey.

[2] Theuerkorn, F. 2005. Lightweight Enterprise Architectures. Auerbach Publications, New York.

[3] Schekkerman, J. 2004. How to survive in the jungle of Enterprise Architecture frameworks. Second edition, Trafford Publishing, Canada.

[4] Ross, J.W., Weill, P. \& Robertson, D.C. 2006. Enterprise Architecture as strategy: Creating a foundation for business execution. Harvard Business School Press, Boston, Massachusetts.

[5] Bernard, S.A. 2005. An introduction to Enterprise Architecture EA3. Second edition, Authorhouse, Bloomington, USA. 
[6] Lankhorst, M. 2005. Enterprise Architecture at work. Springer-Verlag, Berlin, Germany.

[7] Kaplan, R.S. \& Norton, D.P. 1996. The Balanced Scorecard. Harvard Business School Press, Boston, Massachusetts.

[8] Kaplan, R.S. \& Norton, D.P. 2004. Strategy maps: Converting intangible assets into tangible outcomes. Harvard Business School Press, Boston, Massachusetts.

[9] Kaplan, R.S. \& Norton, D.P. 2006. Alignment - using the Balanced Scorecard to create corporate strategies. Harvard Business School Press, Boston, Massachusetts. 2006.

[10] Boar, B. H. 1999. Constructing blueprints for Enterprise IT Architectures. John Wiley, New York.

[11] lyamu, T. 2002. Enterprise Architecture as an enterprise change agent. Thesis in partial fulfilment of the requirements for Masters in Information Management, University of the Western Cape.

[12] Treacy M. \& Wiersma, F. 1995. The discipline of market leaders: Choose your customers, narrow your focus, dominate your market. HarperCollins, London.

[13] Hax, A. \& Wilde, D. 2001. The Delta Project: Discovering new sources of profitability in a networked economy. New York, Palgrave.

[14] Macgregor, S. 2007. EA enduring competitive advantage. Newsletter. June.

[15] Scott, A.B. 2005. An introduction to Enterprise Architecture, second edition. Authorhouse, Bloomington, United States of America. 